\title{
Separation of butachlor and its antibody complex by capillary electrophoresis
}

\section{Letter to editor}

The Herbicide butachlor is one of the widely used herbicides in China, and played an important role in the agricultural production. However, it is stable in the environment, and its residues can enter the food chain and show some of the mutagenicity. ${ }^{1-3}$ Almost all available analytical methodologies have been applied to determine butachlor, including gas chromatography (GC), high performance liquid chromatography (HPLC) coupled with different detectors. ${ }^{46}$ These methods demonstrated good selectivity and reproducibility, however, the sample preparation is time consuming and the detection sensitivity is low. In addition, the above mentioned methods are time consuming, and they are usually need expensive, toxic and environmental unfriendly organic agents. The ELISA method is sensitive, efficient and low cost, but the detection process needs complicated washing and incubation. ${ }^{7}$ In this study, the butachlor hapten (BMPA) was directly labeled with fluoresceinthiocarbamyl hexylenediamine (HDF) as the tracer (BMPA-HDF), ${ }^{8}$ a capillary electrophoresis with laser-induced fluorescence (CE-LIF) method to separate butachlor and its antibody complex was established for the first time.

The FITC-BMPA and antiserum were diluted to the appropriate concentrations with $50 \mathrm{mmol} / \mathrm{L}$ boric acid buffer at $\mathrm{pH}$ 8.0. To perform competitive assay, $100 \mu \mathrm{L}$ of $1.0 \mathrm{nmoL} / \mathrm{L}$ FITC-BMPA was mixed with $20 \mu \mathrm{L}$ of 0 to $50.0 \mathrm{ng} / \mathrm{mL}$ butachlor according to the requirement. And then add $100 \mu \mathrm{L}$ of 200 -fold diluted antiserum to each mixed solution above. After $20 \mathrm{~min}$ of incubation in the dark at room temperature, the samples were analyzed by CE-LIF. To construct the standard curve, a stock solution of butachlor in $\mathrm{MeOH}(1 \mathrm{mg} / \mathrm{mL})$ was diluted with $\mathrm{MeOH}$ into concentrations of $0,2,5,10,20$ and $50 \mathrm{ng} / \mathrm{mL}$ the competitive assay reaction formula.

$$
\mathrm{Ag}+\mathrm{Ag}^{*}+\mathrm{Ab} \rightarrow \mathrm{Ab}-\mathrm{Ag}^{*}+\mathrm{Ab}-\mathrm{Ag}+\mathrm{Ag}^{*}
$$

$\mathrm{Ab}$, polyclonal antiserum anti-butachlor; $\mathrm{Ag}$, butachlor; $\mathrm{Ag}^{*}$, FITC-BMPA; $\mathrm{Ab}-\mathrm{Ag}^{*}$, immuno complex formation

Untreated fused-silica capillary with an inner diameter of $75 \mu \mathrm{m}$ and total length of $60 \mathrm{~cm}$, which was preconditioned by successively flushing with $0.1 \mathrm{~mol} / \mathrm{L} \mathrm{HCl}, 0.1 \mathrm{~mol} / \mathrm{L} \mathrm{NaOH}, \mathrm{dd} \mathrm{H}_{2} \mathrm{O}$ and running buffer for $2 \mathrm{~min}$, respectively. Electrophoresis was performed at $25^{\circ} \mathrm{C}$ using borate buffer $(50 \mathrm{mmol} / \mathrm{L}, \mathrm{pH} 8.0)$ as the running buffer. The samples were injected at $3447.38 \mathrm{~Pa}$ for $5 \mathrm{~s}$. The applied voltage was $2 \mathrm{kV}$. Between runs the capillary was rinsed with $0.1 \mathrm{~mol} / \mathrm{L} \mathrm{NaOH}$ for $1 \mathrm{~min}$, and then a running buffer for $2 \mathrm{~min}$.

We used different separation buffer to ensure enough separation efficiency and resolution, and it was found that the $50 \mathrm{mmoL} / \mathrm{L}$ boric acid buffer at $\mathrm{pH} 8.0$ was suitable for the CEIA separation. The differences in electrophoretic mobilities of the components in the immuno complex cause them to move apart in the electrical field, resulting in dissociation of the immune complex (Figure 1).
Volume 2 Issue 3 - 2015

\author{
Zhang Ting, ${ }^{1,2}$ Liping $\mathrm{H},{ }^{\prime}$ Gang $\mathrm{X}$, 'Yuanming \\ $\mathrm{S},{ }^{\prime}$ ' Jiansheng $\mathrm{F}^{\prime}$ ' Hongtao $\mathrm{L}^{\prime}$ \\ 'College of Food and Biological Technology, Guangzhou City \\ Polytechnic, China \\ ${ }^{2}$ Guangdong Provincial Key Laboratory of Food Quality and \\ Safety, South China Agricultural University, China
}

Correspondence: Zhang Ting, College of Food and Biological Technology, Guangzhou City Polytechnic, Guangdong Provincial Key Laboratory of Food Quality and Safety, South China Agricultural University, China, Email immunoassay@I26.com

Received: December 19,2014 | Published: July 27, 2015

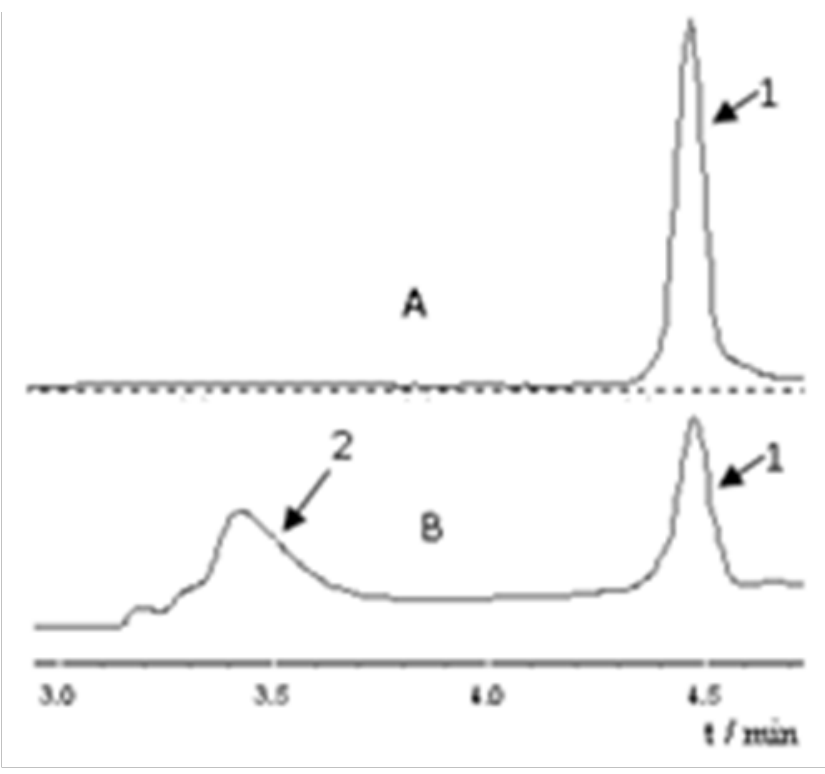

Figure I Electropherograms of BMPA-HDF.

\section{Samples}

A) without antiserum and

B) With antiserum. Buffer: $50 \mathrm{mmol} / \mathrm{L} \mathrm{pH} 8.0$ boric acid buffer; injection: 0.5 p.s.i. $5 \mathrm{~s}$; applied voltage: $25 \mathrm{kV}$; untreated fused-silica capillary: $60 \mathrm{~cm}$ length $(50 \mathrm{~cm}$ effective length), $75 \mu \mathrm{m}$ i.d., Peaks, I=free FITC-BMPA

$\left(A g^{*}\right), 2=$ immunocomplex $\left(A b-A g^{*}\right)$. 


\section{Conclusion}

In conclusion, a simple, sensitive CE-LIF method for the separation of free butachlor and butachlor-antibody complex was established, which will be useful for a further development of an immunoassay based on CE-LIF.

\section{Acknowledgments}

This work was supported by Natural Science Foundation of China (U1301214), Guangdong Natural Science Foundation (S2013030013338), Guangdong Planed Program in Science and Technology (2013B051000072, 2012A020100002, 2012B090600005).

\section{Conflict of interest}

Author declares that there is no conflict of interest.

\section{References}

1. Xu D, Xu Z, Zhu S, et al. Adsorption behavior of herbicide butachlor on typical soils in China and humic acids from the soil sample. $J$ Colloid Interface Sci. 2005;285(1):27-32
2. Yu YL, Wu XM, Li SN, et al. Bioavailability of butachlor and myclobutanil residues in soil to earthworms. Chemosphere. 2005;59(7):961-967.

3. Hill AB, Jefferies PR, Quistad GB, et al. Dialkylquinoneimine metabolites of chloroacetanilde herbicides induce sisterchromatidex change in cultured human lymphocytes. Mutat Res. Genetic Toxicology and Environmental Mutagenesis. 1997;395(2):159-171.

4. Lu M, Ding C. Determination of Acetamide-group Herbicides by High Performance Liquid Chromatography. The Administration and Technique of Environmental Monitoring. 2007;19(3):35-36.

5. Namera A, Watanabe T, Yashiki M, et al. Simple analysis of arylamide herbicides in serum using headspace-solid phase microextraction and GC/MS. Forensic Science International. 1999;103(3):217-226.

6. Tanabe A, Mitobe H, Kawata K, et al. Seasonal and spatial studies on pesticide residues in surface waters of the Shinano River in Japan. $J$ Agric Food Chem. 2001;49(8):3847-3852.

7. Lei H, Xiao Z, Fang J. Preparation of Artificial Antigen and Antibody for Butachlor. Food Science. 2007;28(10):67-70.

8. Xue G, Lei H, Sheng Y. Development of Fluorescence Polarization Immunoassay for the Herbicide Butachlor Synthesis and Identification of Tracers. Scientia Agricultura Sinica. 2008;41(11):3651-3655. 